Article

\title{
Sustainable Fashion Consumption: Advocating Philanthropic and Economic Motives in Clothing Disposal Behaviour
}

\author{
Siti Hasnah Hassan ${ }^{1, *}$, Jasmine A. L. Yeap ${ }^{1}$ and Nabil Hasan Al-Kumaim ${ }^{2}$ D \\ 1 School of Management, Universiti Sains Malaysia, Gelugor 11800, Malaysia; jasmine@usm.my \\ 2 Faculty of Technology Management and Technopreneurship, Universiti Teknikal Malaysia Melaka (UTeM), \\ Melaka 75450, Malaysia; nabil@utem.edu.my \\ * Correspondence: siti.hassan@usm.my
}

check for updates

Citation: Hassan, S.H.; Yeap, J.A.L.; Al-Kumaim, N.H. Sustainable Fashion Consumption: Advocating Philanthropic and Economic Motives in Clothing Disposal Behaviour. Sustainability 2022, 14, 1875 . https://doi.org/10.3390/su14031875

Academic Editor: Lisa McNeill

Received: 1 December 2021

Accepted: 4 February 2022

Published: 7 February 2022

Publisher's Note: MDPI stays neutral with regard to jurisdictional claims in published maps and institutional affiliations.

Copyright: (C) 2022 by the authors. Licensee MDPI, Basel, Switzerland. This article is an open access article distributed under the terms and conditions of the Creative Commons Attribution (CC BY) license (https:// creativecommons.org/licenses/by/ $4.0 /)$.

\begin{abstract}
The fast fashion market is becoming popular, escalating and aggravating the throwaway culture phenomenon. Thus, it is valuable to understand the factors that influence sustainable fashion consumption and the clothing disposal pattern among young consumers in developing countries like Malaysia. Data were obtained from the online survey of 324 young adults aged 18 to 35 and were analysed using the Partial Least Square using SmartPLS (v.3.3.3i). The findings indicate that personal norms, social norms and environmental awareness were the key influencing factors of sustainable fashion consumption. Consequently, sustainable fashion consumption exhibited a positive and significant relationship towards philanthropic and economic reasons for clothing disposal behaviour. The insights from this study will assist practitioners, green manufacturers, business owners and policy makers in giving a clearer picture of what motivates sustainable fashion consumption and the clothing disposal behaviour of today's young adults.
\end{abstract}

Keywords: sustainable fashion consumption; personal norms; social norms; environmental awareness; philanthropic disposal behaviour; economic disposal behaviour

\section{Introduction}

The fashion industry is ever-changing, with new retailers launching new collections at affordable prices and increasing profit margins every few weeks [1,2]. Fast fashion is defined as "a strategic concept to capitalise on rapid inventory turnover through the implementation of a short renewal cycle and limited supply" [3]. The advancement in technology has fuelled fast fashion in ways that allows for rapid production and frequent turnover in an affordable fashion, in which the shelf life of the clothing can only last for a few weeks. Consequently, consumers may not take good care of the clothes due to the low price and discard them without much thought [4]. This rapidly expanding fast fashion trend has resulted in excess clothing consumption, particularly among young consumers, who are more obsessed with fashion trends than any other demographic [2]. The fast fashion trend has escalated and aggravated the throwaway culture phenomenon [1,2,5]. As a result, the fashion sector is responsible for around 10 percent of global carbon emissions and nearly 20 percent of wastewater [6]. In 2050, the global clothing sales are anticipated to exceed 160 million tonnes, driven by market expansions in Asia and Africa, more than 3 times the amount of clothing sold now, resulting in a significant increase in the industry's negative impacts [7].

Fashion has been said to be the most unsustainable and polluting industry $[4,5,8]$. The negative environmental impacts of the fashion industry have raised serious concerns regarding the ethical, social and environmental aspects of irresponsible disposing practices [5]. Despite growing environmental pressure on the fashion industry, the so-called 'fashion paradox' implies that the business is inherently resistant to sustainability since it must evolve to fulfil consumers' desires for the most exclusive fashion. Implicit in the fashion paradox is the contradiction between fashion imperative in style with constant changes 
versus sustainability and responsibility [5]. Consequently, the consumers' consumption behaviours on clothing are no longer sustainable.

Sustainability is a significant issue for the fashion industry due to the greater environmental impact during the production and processing phases of the clothing life cycle [9]. Wei and Jung [10] specified sustainable fashion as the products beneficial to society and the environment in production and consumption activities that contribute to creating a sustainable future for humankind. In simpler terms, sustainable fashion can be understood as environmentally and socially responsible fashion products consumption. Sustainable consumption encompasses many aspects, from the production process to the consumption process in the clothing supply chain. As time passes, implementing a sustainable consumption strategy in the fashion industry becomes incredibly challenging, especially in clothing post-purchase. Post-purchase clothing care and maintenance always have a harmful effect on the environment, and little is known about consumer post-purchase behaviours surrounding apparel hoarding and disposal [11]. The production process may impact clothing sustainability during the usage and disposal stages.

Previously, although consumers generally claimed that they care about the environment, this attitude is not reflected in their sustainable consumption behaviours [12]. Recent studies, however, indicate a shifting tendency, with consumers growing more concerned about sustainable consumption and ready to purchase environmentally friendly items such as second-hand clothes, reduce clothing purchases, and recycle them than previously [13-16]. However, despite studies revealing a substantial association between the contributing factor and clothing disposal behaviour, practitioners, and public policy makers acknowledge a disparity between expectations and reality regarding fashion product consumption and disposal [2]. Hence, there is an increasing need to understand the motivational factors in sustainable fashion consumption, as well as monitor the environmental implications and social sustainability of clothing disposal behaviour for fast fashion, which creates a high level of waste [17]. Consequently, there is still a need to address consumer attitudes regarding sustainable fashion and how consumers dispose of their clothing.

Understanding clothing disposal behaviour is vital because of the long-term environmental impact caused by clothing waste. Thus, the aim of this study was threefold: (a) To assess the factors that affect consumers' sustainable fashion consumption and (b) to inspect the relationship between sustainable fashion consumption and clothing disposal behaviour (philanthropic and economic reasons of disposal behaviour), and (c) to examine the facilitating conditions as a moderating variable that may affect the relationship between sustainable consumption and clothing disposal behaviour (philanthropic and economic reasons of disposal behaviour) of young adult consumers in Malaysia. The findings of this study will provide new insights for attracting different levels of innovative consumers, which further influences their purchasing behaviour and future clothing disposal behaviour.

\section{Literature Review}

Interpersonal behaviour is a multidimensional and complicated phenomenon. A behavioural reaction in any scenario is a consequence of several factors, including the individual's goal, habitual reactions, environmental limits, and other inherent factors in the given situation [18]. Individual behaviour is determined by what a person perceives as suitable in a given situation. The Theory of Interpersonal Behaviour (TIB), founded by Triandis [19], was applied as the foundation of this study. The concept of TIB was derived based on two theories: Theory of Planned Behaviour and Theory of Reasoned Action [20,21].

The TIB is particularly effective when describing and analysing complex human behaviours in socially significant contexts. Triandis [19] asserts that behavioural intention, habit, and facilitating conditions are all significant elements in the behavioural outcome, primarily formed by social and emotional components. Thus, it postulates that individuals usually make decisions based on cognitive and emotional factors [19,22]. The theory indicates that the likelihood of a behaviour depends on the individual's habits, the facilitating 
conditions, and the intention to perform the behaviour [23,24]. As the habitual behaviour becomes more prevalent and the level of consciousness decreases, performing the behaviour becomes a routine $[23,25]$. TIB is becoming increasingly popular in researching determinants of pro-environmental behaviour [24-26].

Sustainable fashion production and consumption encompass many stages, including textile production, apparel manufacture, distribution, post-purchase, and clothing disposal. Responsible consumption and post-consumer behaviour at the retail-consumer interface in the clothing supply chain are crucial for the transition of sustainable consumption to be successful. Thus, understanding the most effective clothing disposal alternatives is critical for long-term waste reduction in landfills. Figure 1 summarises the research framework developed for the study.

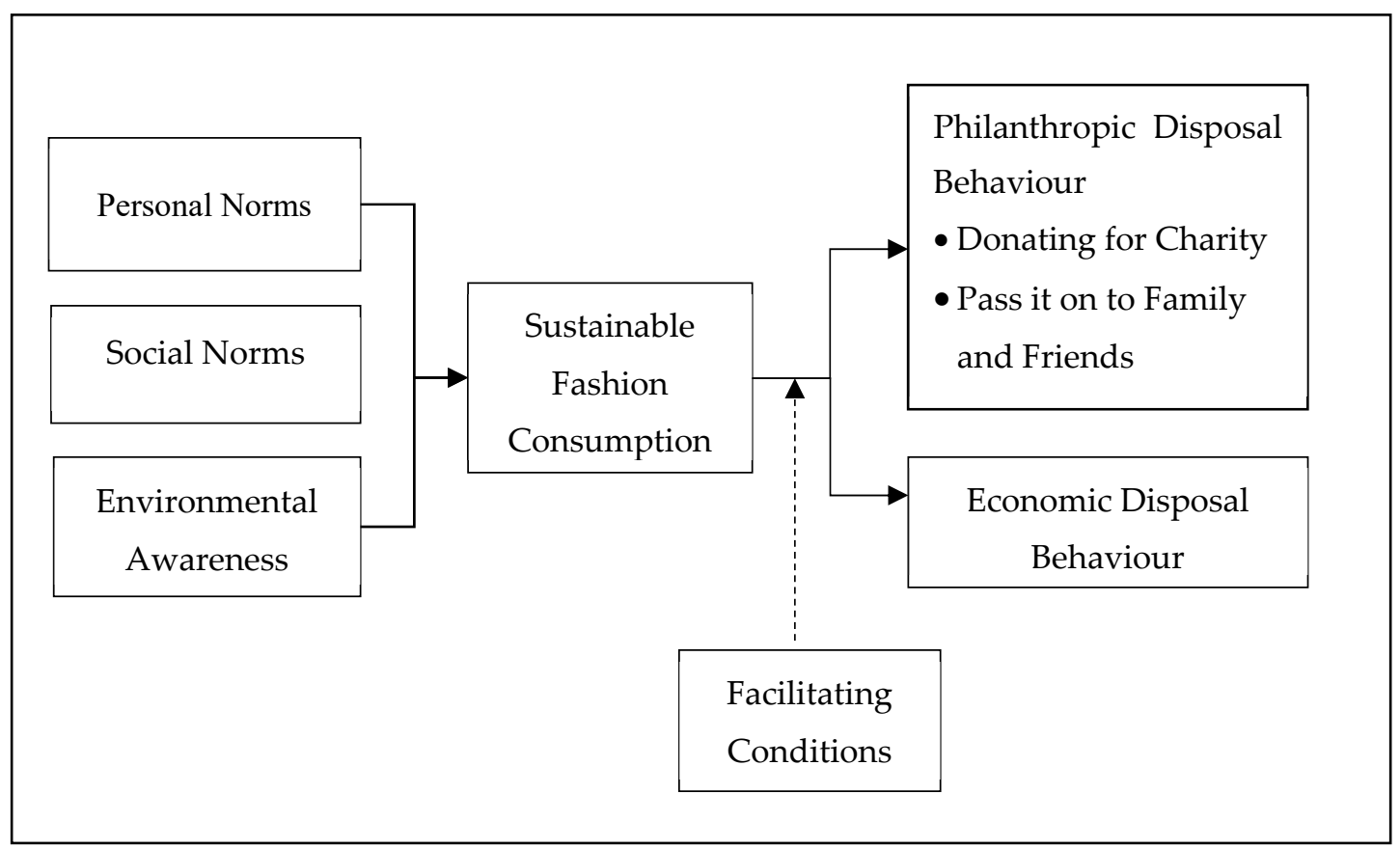

Figure 1. Research Framework.

\subsection{Clothing Disposal Behaviour}

The retail-consumer interface consumption process involves acquisition, consumption, and disposition [27]. Past studies have mainly focused on the decision-making process relating to the product acquisition and consumption stages. Little research has been focused on the clothing disposition stage [11], especially in Malaysia or other developing countries [2]. Therefore, this study mainly focuses on consumers' clothing disposition stage. Disposal is defined as the act of getting rid of something, whether it is discarded as waste or delivered for recycling or reuse [8]. In terms of clothing disposal, it is about why the individual disposes of their clothing, such as poor fit, outdated style, worn out, or boredom. Clothing disposal involves a behavioural action by reusing used clothing, recycling, donating to charities, giving it to a second-hand store, or eliminating it completely, and so on [28]. This study examined clothing disposal behaviour from two perspectives: philanthropic and economic reasons for disposal behaviour as a part of sustainable consumption.

\subsubsection{Philanthropic Disposal Behaviour}

Philanthropy is a social relationship defined by a moral responsibility that links a supply of private resources with a demand for unfulfilled needs and desires conveyed through entreaty or other means of solicitation [29]. Consumers with higher educational levels, environmental knowledge, social status, and who are married usually have a greater 
tendency to display philanthropic dispositions [30]. The consumers will most likely donate and give away the clothes they paid a high price to obtain [31,32].

According to Wai Yee, Hassan [2], consumers who have a philanthropic conscience and wish to make a positive contribution to society would give their unwanted clothing to charity organisations. Some charity facilities provide used clothes recycling services. Some charitable organisations provide a door-to-door collection service for the goods they collect. On the other hand, other charitable organisations place collection boxes in strategic areas, such as neighbouring housing developments or shopping malls, to dispose of or recycle unwanted items. Thus, philanthropic disposal behaviour is associated with individual clothing disposal activities conducted to assist those who are less fortunate.

Another philanthropic clothing behaviour is giving away the clothing to family and friends to swap or donate for the valuable, unfit, or unused clothes [11,28,33]. However, not all individuals are willing to give away or dispose of their valuable unused clothing [28]. Some people retain their clothing even though they have not worn it in a long time because of the value, the fit, the attachment, the aesthetic items, and the guilt of discarding it [11].

\subsubsection{Economic Disposal Behaviour}

Economic disposal behaviour concerns the reselling of unwanted clothing. This is due to the reason that consumers feel guilty about throwing away clothes. Therefore, they sell unwanted clothes to the merchants, which could also help them generate some returning revenue while protecting the environment. In other words, economic concerns have driven people to resell and reuse clothing [34]. Past studies also discovered that consumers, regardless of educational level, displayed the economic dispositions in their disposal behaviours, such as reselling the high-value clothes they acquired to earn some returning revenue $[2,27,31,32]$. In addition, a financial crisis might trigger the economic reasons for the disposal behaviours of the consumers.

\subsection{Personal Norms}

Personal norms can be defined as the feelings of strong moral obligation to engage in altruistic or green behaviour [35]. An individual's altruistic behaviour is derived from a moral obligation and an internal structure of values [36]. Therefore, personal norms can be highly related to moral obligation. A person with high personal norms may be motivated by an inner desire to act pro-environmentally, whereas those with low personal norms might hinder the behaviour. Past studies have examined the correlation between personal norms and various pro-environmental behaviours [13,16,37]. A study revealed that moral obligation had favourable and substantial effects on purchase intentions of organic, fairtrade, and recycled clothing products [37]. Young consumers' personal values have shifted from being self-centred to being more society-centred due to the growing concerns about environmental damage and social inequality in the fashion industry [38]. Joanes [16] also discovered a positive and substantial relationship between personal norms and the intention to minimise personal clothing consumption. Thus, hypothesis $\mathrm{H} 1$ was developed to test the relationship between personal norms and sustainable fashion consumption.

Hypothesis 1 (H1). Personal norms are positively and significantly associated with sustainable fashion consumption.

\subsection{Social Norms}

Social norms are shared beliefs about proper behaviour within a community regarding how we respond to a situation [39]. Injunctive and descriptive social norms are the information about effective behaviour based on the perception of what others do [40]. Marketers need to understand how to adjust social norms to the specific contexts to motivate sustainable consumption to make products more ethical and environmentally friendly for future generations. Social norms have been shown to positively impact various behavioural domains in sustainable behaviour [39,41,42]. Doran and Larsen [41] found that people 
were more likely to engage in pro-environmental behaviour when they receive messages, including information indicating that people around them are also doing the same things. Borusiak, Szymkowiak [13] also explained that individuals usually feel pressured to engage in a specific behaviour from the people around them. Moreover, observing other people contribute to a common cause, such as environmental preservation, might enhance the trust in cooperative intentions of other people, strengthen beliefs in achieving the desired outcome, and improve people's willingness to contribute their share in environmental preservation [42]. In view of the preceding discussion, hypothesis $\mathrm{H} 2$ was established to examine the relationship between social norms and sustainable fashion consumption.

Hypothesis 2 (H2). Social norms are positively and significantly associated with sustainable fashion consumption.

\subsection{Environmental Awareness}

In recent years, sustainability issues, such as the ineffective disposal of textiles in the apparel industry, have received heightened attention from scholars in developed and developing countries $[14,15,43,44]$. There is a concern that a huge amount of textile waste is disposed of in landfills each year, causing pollution and chemical hazards, including pesticides, dye waste, and emissions. Textile manufacturers have started to implement various environmentally and socially responsible initiatives throughout their supply chains to reduce the environmental impact of the fast fashion trend.

Past scholars have agreed that environmental awareness and attitudes better predict sustainable behaviours $[28,44,45]$. Consumers that place a high value on environmental stewardship tend to be more environmentally conscious and recycle unwanted clothing more willingly than those who are not. $\mathrm{Ho}, \mathrm{Vu}[44]$ discovered a positive and significant relationship between environmental knowledge and purchase intention of sustainable fashion. The positive relationship comes from the consumers who have better environmental knowledge. They are more likely to contribute to solving environmental issues than those less concerned about the impact of fast fashion on the environment [7]. Puspita and Chae [46] found a cultural difference in environmental awareness between Western and Asian countries. Western consumers are often more environmentally conscientious and willing to pay a premium for fashion products than Asian consumers, who remain price-sensitive [46]. Hence, hypothesis $\mathrm{H} 3$ was formulated to examine the relationship between environmental awareness and sustainable fashion consumption.

Hypothesis $3 \mathbf{~ ( H 3 ) . ~ E n v i r o n m e n t a l ~ a w a r e n e s s ~ i s ~ p o s i t i v e l y ~ a n d ~ s i g n i f i c a n t l y ~ a s s o c i a t e d ~ w i t h ~}$ sustainable fashion consumption.

\subsection{Sustainable Fashion Consumption}

The sustainable fashion issue has received a lot of attention in marketing studies. Various concepts or terms connected to sustainable fashion, such as ethical fashion, green fashion, and eco-fashion, are reflected in the literature. Sustainable consumption is defined as "consumption that supports the ability of current and future generations to meet their material and other needs, without causing irreversible damage to the environment or loss of function in natural systems" [47]. It also refers to products that benefit society and the environment in manufacturing and consumption processes and contribute to forming a sustainable future for humankind [10].

There are three stages in sustainable fashion consumption: production, purchase, and post-purchase stages. In post-purchase sustainable fashion, consumption has been linked to the disposal stage, such as reusability, reconditioning, and reselling unwanted clothes $[28,43]$. Cho, Gupta [48] reported the association among style-conscious, sustainable purchase, and disposal behaviours. Environmentally conscious consumers are more likely to recycle or dispose of their clothes not to harm the environment or cause pollution. Pro- 
environmental consumers tend to dispose of their unwanted clothing in sustainable ways such as recycling or redesigning the clothes to reduce the environmental damage caused by inefficient clothing disposal [27]. In addition, consumers usually will also dispose of their clothing by donating them to charities, passing them to family and friends, reselling them to a second-hand store, or eliminating them, and so on [11,28,33].

Based on the discussion of clothing disposal behaviour above, hypotheses $\mathrm{H} 4$, $\mathrm{H} 5$, and H6 were developed to examine the relationship between sustainable fashion consumption and clothing disposal behaviour, either philanthropic disposal behaviour (donating to charity or passing it on to family and friends) or disposal for economic reasons.

Hypothesis 4 (H4). There is a positive and significant relationship between sustainable fashion consumption and philanthropic disposal behaviour by donating clothes to charity.

Hypothesis 5 (H5). There is a positive and significant relationship between sustainable fashion consumption and philanthropic disposal behaviour by passing on the clothes to family and friends.

Hypothesis 6 (H6). There is a positive and significant relationship between sustainable fashion consumption and economic reasons for disposal behaviour.

\subsection{Facilitating Conditions}

An individual may intend to execute specific conduct but might be prevented from doing so by their environment- these externally favourable environmental factors, often known as facilitating conditions. Thus, facilitating conditions include an individual's capability to perform the act, their level of interest in the act, the difficulty of completing the act, the knowledge on the need to perform the act, and the surrounding setting that increase the intention to perform the act. The Theory of Interpersonal Behaviour (TIB) explains that behaviour is shaped by an individual's intention to engage in action and the facilitating conditions of present situational constraints and conditions [19]. According to the theory, facilitating conditions may favourably or adversely impact behaviour. Moreover, behaviour is moderated by the facilitating conditions that significantly impact the final behaviour performed.

A study has shown that the more favourable the facilitating conditions, the higher the participation rate, whereas insufficient accessibility resulted in a low participation rate, regardless of the consumers' pro-environmental consumption behaviour of fashion products [49]. Regardless of the levels of habit or intention, facilitating conditions play a critical role in their presence or their absence. In this study, the facilitating conditions function as a moderator towards clothing disposal behaviour. The facilitating condition will moderate a philanthropic behaviour either to give the clothing to charity, family, and friends or to dispose of the clothing for economic reasons. Based on the discussion above, hypotheses $\mathrm{H7}, \mathrm{H} 8$, and $\mathrm{H} 9$ for the moderating effects of facilitating conditions were suggested as follows.

Hypothesis 7 (H7). Facilitating conditions moderate the relationship between sustainable fashion consumption and philanthropic disposal behaviour by donating to charity.

Hypothesis 8 (H8). Facilitating conditions moderate the relationship between sustainable fashion consumption and philanthropic disposal behaviour.

Hypothesis 9 (H9). Facilitating conditions moderate the relationship between sustainable fashion consumption and economic reasons for disposal behaviour. 


\section{Methodology}

\subsection{Sampling and Data Collection Methods}

The target respondents in this study were young adults from 18 to 35 years old residing in Malaysia. Consumers, especially women under 35, are considered fast fashion shoppers [50]. A recent study on lifespan development and prior studies emphasised that the extended transition has resulted in young adults ranging from 18 to 35 years old [51]. This group is considered fashion-conscious and frequently buys on impulse to be trendy. Choosing a suitable sample size when using the Structural Equation Modelling is essential because the sample size can affect the statistical test result by making it overly sensitive to very large sample sizes or insensitive to small sample sizes. The minimum sample size is recommended to be five times the number of items in latent variables, while the maximum sample size is ten times the number of items in latent variables [52]. The survey form contains approximately 40 items. Thus, the sample size should be between 200 and 400 samples. Social media platforms, such as Facebook, Instagram, and WhatsApp, were used to reach the intended respondents. The respondents were ensured regarding confidentiality concerns using the snowballing sampling technique.

\subsection{Measurement Items}

The survey method was employed using a self-administrated questionnaire (Table A1) as the data collection technique. The measurement items for the variables in the questionnaire were derived from previously published studies. There are two dimensions of the dependent variables for philanthropic clothing disposal. The first dimension was giving away to family and friends (PCDB.FF), and the items for this variable were adapted from Bianchi and Birtwistle [28]. The second dimension was giving charity (PCDB.CH), which was adapted from Shim [27]. The items for economic clothing disposal behaviour were adapted from Shim [27]. The personal and social norms items were adapted from Kim and Seock [53]. The environmental awareness items were adapted from Butler and Francis [54] and Bianchi and Birtwistle [28], sustainable fashion consumption items were adapted from Moon, Lai [55] and Butler and Francis [54], and finally, the facilitating condition items were adapted from Botetzagias, Dima [56].

\section{Results}

A total of 324 responses from the online survey were collected at the end of the data collection process. Out of the 324 respondents, 62 percent were female, while 38 percent were male. The age ranges of the respondents are from 18 to $23(72.8 \%), 24$ to $29(15.1 \%)$, and 30 to 35 (12.0\%). Most respondents were bachelor-degree holders (85.8\%) concerning their educational background. Others were either diploma holders, matriculation or a higher level of high school certification (10.8 percent), master's degree holders (1.9 percent), PhD holders ( 0.9 percent), or had a high school education (0.6 percent).

\subsection{Measurement Model}

The test was established to determine the validity and reliability of the measurement model. Factor loadings, Cronbach's alpha ( $\alpha$ ), and composite reliability (CR) were used to test the model's reliability [57]. Convergent validity was assessed using average variance extracted (AVE), which indicates the amount of variation explained by the concept in its respective indicators [57]. Table 1 shows that all factors had loadings more than $0.7, \alpha$ greater than 0.7 , and CR greater than 0.7 , supporting the measurement model's reliability at the item and construct levels. Table 1 indicates that all factors show loadings of more than $0.7, \alpha>0.7, C R>0.7$, and AVE greater than 0.50, thus, confirming the reliability and validity of the measurement model at the item and construct levels. 
Table 1. Measurement Model.

\begin{tabular}{|c|c|c|c|c|c|c|}
\hline Constructs & Items & Loadings & $\alpha(>0.7)$ & rho_A & $\mathrm{CR}(>0.7)$ & $\operatorname{AVE}(>0.5)$ \\
\hline \multirow{4}{*}{ Personal Norms } & PN1 & 0.750 & \multirow{4}{*}{0.828} & \multirow{4}{*}{0.851} & \multirow{4}{*}{0.884} & \multirow{4}{*}{0.656} \\
\hline & PN2 & 0.814 & & & & \\
\hline & PN3 & 0.850 & & & & \\
\hline & PN4 & 0.821 & & & & \\
\hline \multirow{4}{*}{ Social Norms } & SN1 & 0.808 & \multirow{4}{*}{0.812} & \multirow{4}{*}{0.818} & \multirow{4}{*}{0.876} & \multirow{4}{*}{0.640} \\
\hline & SN2 & 0.830 & & & & \\
\hline & SN3 & 0.834 & & & & \\
\hline & SN4 & 0.724 & & & & \\
\hline \multirow{4}{*}{ Environmental Awareness } & EN1 & 0.722 & \multirow{4}{*}{0.765} & \multirow{4}{*}{0.771} & \multirow{4}{*}{0.849} & \multirow{4}{*}{0.585} \\
\hline & EN2 & 0.778 & & & & \\
\hline & EN3 & 0.757 & & & & \\
\hline & EN4 & 0.801 & & & & \\
\hline \multirow{5}{*}{ Facilitating Conditions } & FC1 & 0.821 & \multirow{5}{*}{0.861} & \multirow{5}{*}{0.865} & \multirow{5}{*}{0.899} & \multirow{5}{*}{0.641} \\
\hline & FC2 & 0.809 & & & & \\
\hline & FC3 & 0.803 & & & & \\
\hline & FC4 & 0.784 & & & & \\
\hline & FC5 & 0.786 & & & & \\
\hline \multirow{6}{*}{ Sustainable Fashion Consumption } & SFC1 & 0.703 & \multirow{6}{*}{0.818} & \multirow{6}{*}{0.820} & \multirow{6}{*}{0.868} & \multirow{6}{*}{0.523} \\
\hline & SFC2 & 0.701 & & & & \\
\hline & SFC3 & 0.693 & & & & \\
\hline & SFC4 & 0.746 & & & & \\
\hline & SFC5 & 0.756 & & & & \\
\hline & SFC6 & 0.739 & & & & \\
\hline \multirow{4}{*}{$\begin{array}{l}\text { Philanthropic Clothing Disposal } \\
\text { Behaviour-Family and Friends }\end{array}$} & PCDB1 & 0.785 & \multirow{4}{*}{0.818} & \multirow{4}{*}{0.828} & & \\
\hline & PCDB2 & 0.792 & & & & \\
\hline & PCDB3 & 0.833 & & & 0.878 & 0.644 \\
\hline & PCDB4 & 0.798 & & & & \\
\hline & PCDB5 & 0.867 & & & & \\
\hline Philanthropic Clothing Disposal & PCDB6 & 0.858 & 0.775 & 0.785 & 0.870 & 0.691 \\
\hline & PCDB7 & 0.765 & & & & \\
\hline & ECDB1 & 0.907 & & & & \\
\hline Economic Clothing Disposal & ECDB2 & 0.905 & & & & \\
\hline Behaviour & ECDB3 & 0.897 & 0.893 & 0.905 & 0.926 & 0.759 \\
\hline & ECDB4 & 0.768 & & & & \\
\hline
\end{tabular}

Notes: $\alpha=$ Cronbach's alpha; $\mathrm{CR}=$ Composite reliability; $\mathrm{AVE}=$ Average variance extracted.

Discriminant validity was proven using Fornell and Larcker's [58] recommendation, namely, that the square root of the AVE must be higher than the sum of all correlations in row and column. The diagonal values of all constructions surpassed the off-diagonal values in row and column for the same construct as shown in Table 2, indicating good discriminant validity. 
Table 2. Fornell-Larcker Criterion.

\begin{tabular}{ccccccccc}
\hline & ECDB & EA & FC & PN & PCDB_CH & PCDB_FF & SN & SFC \\
\hline ECDB & $\mathbf{0 . 8 7 1}$ & & & & & & & \\
\hline EA & 0.193 & $\mathbf{0 . 7 6 5}$ & & & & & & \\
\hline FC & 0.346 & 0.131 & $\mathbf{0 . 8 0 1}$ & & & & & \\
\hline PN & 0.407 & 0.350 & 0.290 & $\mathbf{0 . 8 1 0}$ & & & \\
\hline PCDB_CH & 0.353 & 0.280 & 0.330 & 0.234 & $\mathbf{0 . 8 3 1}$ & & \\
\hline PCDB_FF & 0.568 & 0.252 & 0.373 & 0.429 & 0.401 & $\mathbf{0 . 8 0 2}$ & & \\
\hline SN & 0.382 & 0.483 & 0.187 & 0.619 & 0.283 & 0.395 & $\mathbf{0 . 8 0 0}$ & \\
\hline SFC & 0.330 & 0.634 & 0.172 & 0.462 & 0.350 & 0.322 & 0.527 & $\mathbf{0 . 7 2 3}$ \\
\hline
\end{tabular}

Note: Values in diagonal (bolded) are the square root of the average variance extracted. ECDB = Economic Clothing Disposal Behaviour; EA $=$ Environmental Awareness; FC $=$ Facilitating Conditions; $\mathrm{PN}=$ Personal Norms; PCDB.CC = Philanthropic Clothing Disposal Behaviour Give Charity; PCDB.CC = Philanthropic Clothing Disposal Behaviour Give family and Friend; SN = Social Norms; SFC = Sustainable Fashion Consumption.

The Heterotrait-Monotrait Ratio (HTMT) was also used to evaluate the discriminant validity to overcome the Fornell-Larcker criterion's insensitivity. According to Henseler, Hubona [59] HTMT is recommended as a higher boundary criterion for assessing discriminant validity. Two alternative cut-off values of 0.85 and 0.90 have been proposed to establish discriminant validity for the HTMT criteria [59]. The values in Table 3 range from 0.228 to 0.790 . These values are substantially lower than the threshold values, showing that all constructs are explicitly independent of one another and that the discriminant validity requirement has been fulfilled.

Table 3. Heterotrait-Monotrait Ratio (HTMT) Test.

\begin{tabular}{ccccccccc}
\hline & ECDB & EA & FC & PN & PCDB_CH & PCDB_FF & SN & SFC \\
\hline ECDB & & & & & & & \\
\hline EA & 0.228 & & & & & & \\
\hline FC & 0.386 & 0.165 & & & & & \\
\hline PN & 0.497 & 0.403 & 0.339 & & & & \\
\hline PCDB.CH & 0.423 & 0.368 & 0.394 & 0.280 & & & \\
\hline PCDB.FF & 0.649 & 0.332 & 0.420 & 0.504 & 0.500 & & \\
\hline SN & 0.447 & 0.603 & 0.224 & 0.747 & 0.362 & 0.484 & \\
\hline SFC & 0.377 & 0.790 & 0.201 & 0.530 & 0.438 & 0.392 & 0.636 \\
\hline
\end{tabular}

Note: Shaded boxes are the standard reporting format for HTMT ratios. ECDB = Economic Clothing Disposal Behaviour; EA = Environmental Awareness; FC = Facilitating Conditions; PN = Personal Norms; PCDB.CC = Philanthropic Clothing Disposal Behaviour Give Charity; PCDB.CC = Philanthropic Clothing Disposal Behaviour Give family and Friend; SN = Social Norms; SFC = Sustainable Fashion Consumption.

\subsection{Structural Measurement Model}

The structural model was evaluated using multiple criteria, including the model's explanatory power $\left(\mathrm{R}^{2}\right)$, path coefficient $(\mathrm{b})$ and related $t$-values, effect size $\left(\mathrm{f}^{2}\right)$, and predictive relevance $\left(Q^{2}\right)$ [57]. As a general guideline, an $R^{2}$ value of 0.25 is weak, 0.50 is moderate, and 0.75 is substantial; nevertheless, the $\mathrm{R}^{2}$ should be interpreted in the study context to the associated studied field [57]. According to Cohen [60], the $\mathrm{R}^{2}$ value can be assessed as substantial $=0.26$, moderate $=0.13$, and weak $=0.02$. If this guideline is used, the results reveal that the $R^{2}$ value of sustainable fashion consumption is 0.45 , indicating that the factors explain $45.0 \%$ of the variance. The $\mathrm{R}^{2}$ value of the philanthropic clothing disposal behaviour for giving to charity is 0.216 and passing it on to family and friends is 0.255 , while the $\mathrm{R}^{2}$ value of the economic clothing disposal behaviour is 0.252 . Thus, this indicates that $21.6 \%$ and $25.5 \%$ of the philanthropic clothing disposal behaviour variance can be explained substantially. Meanwhile, $25.2 \%$ of the economic clothing disposal behaviour variance can also be explained substantially by the variables.

The effect size $\left(\mathrm{f}^{2}\right)$ assesses the individual influence of a given independent variable on the dependent variable. Cohen [60] defines effect size $\left(\mathrm{f}^{2}\right)$ values of $0.02,0.15$, and 0.35 as representing the small, medium, and large effects, respectively, on an exogenous latent 
variable. Effect size values of less than 0.02 imply that no effect exists. As presented in Table 4 , the personal norm value $\left(f^{2}=0.039\right)$ and the social norm value $\left(f^{2}=0.039\right)$ exert a weak effect on sustainable fashion consumption. In contrast, environmental awareness exerts a strong effect on sustainable fashion consumption $\left(\mathrm{f}^{2}=0.345\right)$. Sustainable fashion consumption exerts a moderate effect on the philanthropic behaviour of giving away to charity $\left(\mathrm{f}^{2}=0.109\right)$. Likewise, sustainable fashion consumption exerts a small effect on the philanthropic behaviour of giving to family and friends $\left(\mathrm{f}^{2}=0.090\right)$ and economic disposing behaviour $\left(\mathrm{f}^{2}=0.089\right)$.

Blindfolding was used to assess the predicted relevancy $\left(\mathrm{Q}^{2}\right)$ value. According to [61], if the $Q^{2}$ values are larger than zero, the model has predictive significance, while Hair Jr, Sarstedt [52] propose values of 0.35 (large), 0.15 (medium), and 0.02 (small) as a measure of predictive relevance. As shown in Table 4 , all the $\mathrm{Q}^{2}$ values are larger than zero, suggesting that the suggested model has appropriate predictive significance.

The bootstrap procedure with 5000 subsamples was used to determine the significance level of the path analysis for hypotheses testing. Table 4 and Figure 2 show the path coefficients' values and the hypotheses' $t$-value. According to Hair Jr, Sarstedt [57], the T-statistic values are greater than the threshold value of 1.96, demonstrating the significance of the relationship between the variables.

Table 4. Path Coefficient.

\begin{tabular}{|c|c|c|c|c|c|c|c|c|c|}
\hline Path (Hypotheses) & $\begin{array}{c}\text { Standard } \\
\text { Beta }\end{array}$ & $\begin{array}{l}\text { Standard } \\
\text { Error }\end{array}$ & $t$-Value & LL & UL & Decision & $\mathbf{R}^{2}$ & $\mathbf{f}^{2}$ & $\begin{array}{c}\mathrm{Q}^{2}(=1- \\
\text { SSE/SSO) }\end{array}$ \\
\hline $\mathrm{PN} \rightarrow \mathrm{SFC}(\mathrm{H} 1)$ & 0.181 & 0.086 & 2.133 & 0.040 & 0.322 & Accepted & \multirow{3}{*}{0.485} & 0.039 & \multirow{3}{*}{0.246} \\
\hline $\mathrm{SN} \rightarrow \mathrm{SFC}(\mathrm{H} 2)$ & 0.183 & 0.081 & 2.209 & 0.050 & 0.315 & Accepted & & 0.039 & \\
\hline $\mathrm{EA} \rightarrow \mathrm{SFC}(\mathrm{H} 3)$ & 0.482 & 0.053 & 9.150 & 0.395 & 0.569 & Accepted & & 0.345 & \\
\hline $\mathrm{SFC} \rightarrow$ PCDB.CH (H4) & 0.275 & 0.054 & 5.112 & 0.186 & 0.365 & Accepted & 0.216 & 0.109 & 0.108 \\
\hline $\mathrm{SFC} \rightarrow$ PCDB.FF (H5) & 0.263 & 0.065 & 3.891 & 0.156 & 0.370 & Accepted & 0.255 & 0.090 & 0.121 \\
\hline $\mathrm{SFC} \rightarrow \mathrm{ECDB}(\mathrm{H} 6)$ & 0.262 & 0.056 & 4.753 & 0.169 & 0.355 & Accepted & 0.252 & 0.089 & 0.167 \\
\hline
\end{tabular}

Thus, based on the results, it is confirmed that personal norms $(\beta=0.181, t=2.133)$, social norms ( $\beta=0.183, t=2.209)$, and environmental awareness $(\beta=0.482, t=9.150)$ are significant and positively affect sustainable fashion consumption. The relationship between sustainable fashion consumption and philanthropic clothing disposal behaviour is significant and positive at $\beta=0.275, t=5.112$ for giving to charity and at $\beta=0.263$, $t=3.891$. The relationship between sustainable fashion consumption and economic reasons of clothing disposal behaviour is also significant and positive at $\beta=0.262, t=$ value 4.753 . Therefore, H1, H2, H3, H4, H5, and H6 were all accepted.

\subsection{The Moderating Effect of Facilitating Conditions}

Moderating effects were tested to determine whether facilitating conditions could strengthen or weaken the relationship among sustainable fashion consumption, philanthropic clothing disposal behaviour, and economic reasons for clothing disposal behaviour. The findings of the PLS analysis in Table 5 show that facilitating conditions has no statistically significant moderating effect on the relationship between sustainable fashion consumption and philanthropic clothing disposal behaviour or economic clothing disposal behaviour. Based on this result, hypotheses $\mathrm{H} 7, \mathrm{H} 8$, and $\mathrm{H} 9$ were rejected. 
Table 5. Moderating Effect.

\begin{tabular}{ccccccc}
\hline Path (Hypotheses) & Standard Beta & Standard Error & $\boldsymbol{t}$-Value & LL & UL & Decision \\
\hline SFC $^{*}$ FC $\rightarrow$ PCDB.CH (H7) & -0.124 & 0.153 & 0.799 & -0.376 & 0.128 & Rejected \\
\hline SFC $^{*} \mathrm{FC} \rightarrow$ PCDB.FF (H8) & -0.194 & 0.207 & 0.945 & -0.535 & 0.146 & Rejected \\
\hline SFC $^{*} \mathrm{FC} \rightarrow$ ECDB (H9) & -0.206 & 0.220 & 0.931 & -0.568 & 0.156 & Rejected \\
\hline
\end{tabular}

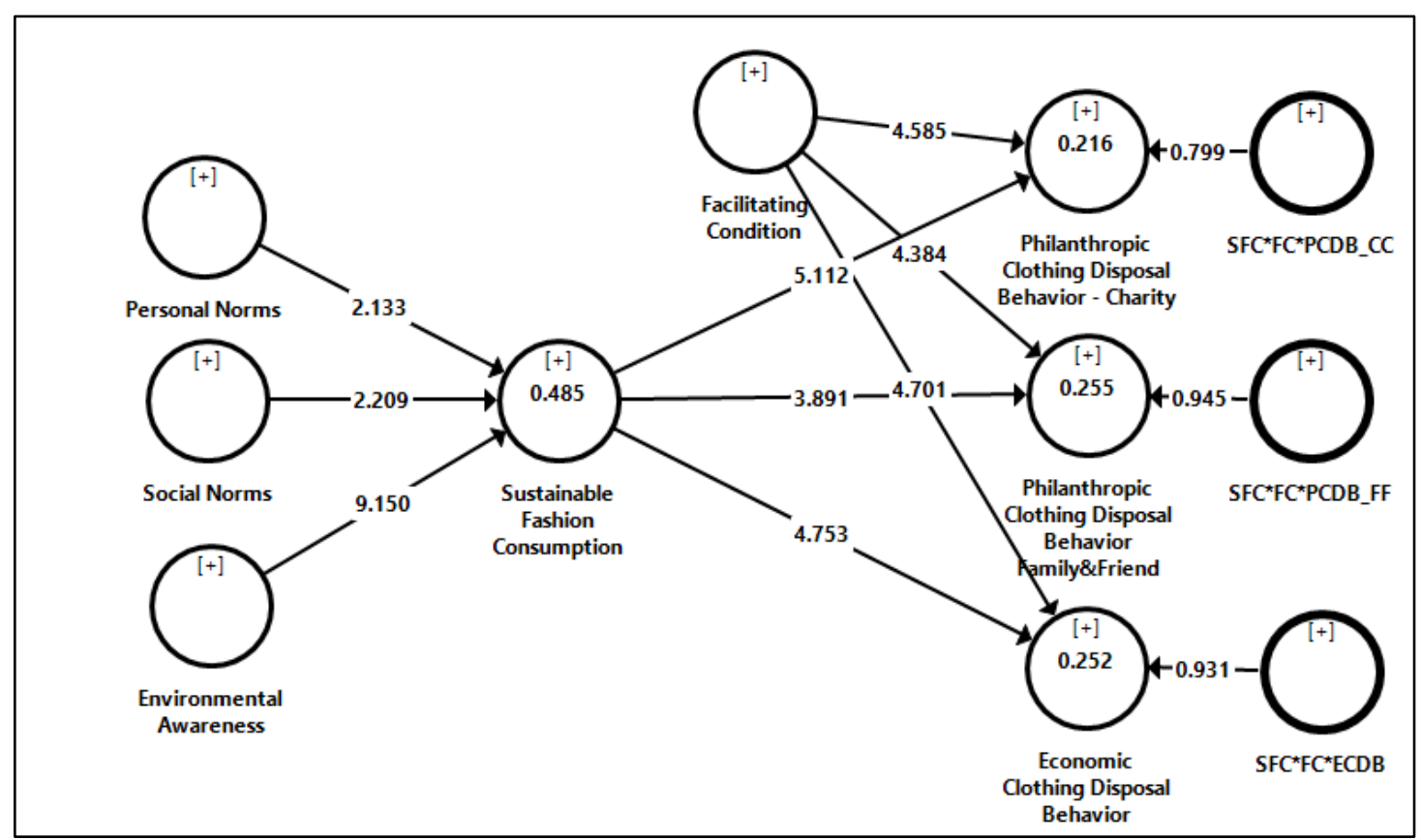

Figure 2. Structural Model.

\section{Discussion}

The results indicated that personal norms, social norms, and environmental awareness impact sustainable fashion consumption positively and significantly. Sustainable fashion consumption affects philanthropic clothing disposal behaviour and the economic reasons of clothing disposal behaviour among Malaysian youth. The findings deduced that environmental awareness exhibited a stronger positive relationship with sustainable fashion consumption, consistent with prior studies [28,44,45]. Young individuals with a high environmental awareness tend to solve environmental issues and exhibit a high level of concern towards the impact of fast fashion on the environment in the long run. Environmental concern has been linked to actual belief, emotion, and commitment to environmental issues [62]. Consequently, people who understand how clothing products will negatively affect the environment tend to purchase sustainable clothes, such as eco-friendly products

In addition, social norm is also concluded to positively affect sustainable fashion consumption, which is in line with previous research [39,41,42]. Consumers who have environmentally conscious family, friends, and colleagues might feel pressured to engage in pro-environmental behaviour because they receive information that the people around them are doing the same things $[13,41]$. This is especially true for young consumers, who place a high value on the view of their peers.

Personal norm is substantial but appears to have the least impact compared to other factors that influence sustainable fashion consumption, which is in line with past studies on pro-environmental behaviour $[13,16,37]$. This study indicates that young adults feel responsible and aware of the effects of their behaviours on the environment. The rising 
concerns about environmental degradation and social inequality in the fashion industry have shifted consumers' values from being more society-centred.

The results reveal that sustainable fashion consumption among young adults impacts both philanthropic and economic reasons for clothing disposal. There are two methods for philanthropic clothing disposal: first, donating the clothes for charity purposes, and second, giving them away to family and friends. The result is in line with past studies on these disposal behaviours $[28,43]$. It suggests that young adults are concerned about sustainable fashion consumption. Donating unwanted clothes to charitable organisations or giving them to family and friends is seen as a solution to minimise the impact on the environment. Another method to dispose of unwanted clothes is to sell them for economic reasons, which is in line with the findings of a previous study $[2,63]$. Young adults are willing to resell or reuse their clothes to lessen their guilt for their overconsumption frequency of fast-fashion clothing. The method can also help young adults to earn extra income when they resell their clothes to other people-selling and buying pre-loved, branded, fashionable items is becoming popular among consumers.

\section{Moderating Effect of Facilitating Conditions}

Based on the moderating testing, the results show no moderating effect of sustainable fashion consumption either on philanthropic clothing disposal behaviour or economic reasons of clothing disposal behaviour in the study. This result can be interpreted in that fashion consumers have already engaged in sustainable clothing disposal behaviour. Therefore, facilitating conditions are deemed an unimportant factor in enhancing their clothing disposal behaviour. Another explanation is that the facilitating conditions are not ideal for developing countries, such as Malaysia. The unwanted clothing may be difficult to dispose of in many parts of Malaysia due to the lack of disposal facilities or the inability to locate charitable organisations that collect unwanted clothing in some areas.

\section{Implications}

This study has given a more profound understanding of the sustainable consumption stage, including knowledge about the factors that impact sustainable fashion consumption and insight into how young consumers dispose of unwanted clothing. This knowledge is relevant to practitioners, policy makers, and government officials since it is the key to effective implementation of strategies related to sustainable consumption. Imposing pro-environmental practices can increase customer awareness of their environmental responsibility, particularly young consumers [64]. Creating a variety of environmental awareness campaigns and recycling facilities can promote a high percentage of clothing recycling among the young adults in the community. Charity organisations, for example, must develop an effective strategy to reach out to young consumers and urge them to recycle regularly. Another way is relevant authorities or NGOs introduce a platform where second-hand clothing can be sold as this will assist the young generation in disposing of clothing properly. The strategies of encouraging young adult consumers to recycle, such as reselling fashion items via platforms and gaining monetary rewards while helping to minimise textile waste, may be devised.

Furthermore, the pre-owned fashion market is expanding due to the increased demand for second-hand fashion products [65]. This is fuelling growth in fashionable areas of the global retail market by purchasing and selling pre-loved items. Online marketplaces are becoming increasingly popular among youth, who reportedly utilise them to buy and sell pre-loved fashion items such as vintage shoes, accessories, and even old band T-shirts. The applications include SellEzmudah.com, Carousell Malaysia, and social media networks as a platform to sell and buy the products [66]. The second-hand clothing revolution can significantly impact the popularity of fast fashion businesses and reshape the fashion industry in the future. The trend will also help reduce the negative environmental impact of the fashion industry on the planet. 
In addition, fashion industries, such as fashion designers, clothing manufacturers, and fashion retailers, can work together to support reverse supply chain management in the fashion industry to encourage sustainable fashion consumption among young adults. Returning unwanted clothing to the retail brands helps to manage the unwanted clothing properly. Although the reverse supply chain in the clothing industry is complex, more arduous regulation execution by key authorities is critical to its success [67]. In addition, as consumers become more concerned about the environment, producers and designers can use more environmentally friendly materials to design and produce fashion products.

\section{Limitation of the Study}

Despite the valuable findings, this study has several limitations that will need to be addressed in future research. Firstly, the result could not be generalised worldwide due to its limited geographic reach. Secondly, the study's sample was limited to young individuals aged 18 to 35 in Malaysia and mainly looked at variables linked to personal norms, social norms, and environmental awareness in evaluating sustainable consumption and clothing disposal behaviour. Thus, future research must broaden its scope to incorporate other factors affecting the research outcome. Moreover, the prospective study could employ different advanced modelling approaches in addition to structural equation modelling using partial least squares.

\section{Conclusions}

Rapid growth is seen by the trendy, cheap fast-fashion industry, which can be purchased and discarded easily. Nevertheless, the post-purchase behaviours of young adult consumers in the fast fashion industry have mostly gone unnoticed until recently. This research was carried out to provide an essential insight into sustainable fashion consumption and philanthropic and economic reasons for clothing disposal behaviour among young adult consumers in Malaysia. The study outcomes indicated that environmental knowledge, personal norms, and social norms directly affect sustainable fashion consumption. Sustainable fashion consumption directly relates to philanthropic and economic reasons for clothing disposal behaviour among young adults in Malaysia. Waste management is a significant challenge to society, government, and practitioners. The current study provides policy makers and other relevant agencies with insights into reducing textile waste. The study has highlighted sustainable clothing disposal behaviour alternatives, such as passing clothing on to family and friends, donating it to charity, or reselling unwanted clothing for profit to reduce the negative environmental impact.

Author Contributions: Study conceptualisation, methodology, data collection, and analysis were conducted by S.H.H. The results, discussion, and reviewing and editing were carried out by S.H.H., J.A.L.Y., and N.H.A.-K. All authors have read and agreed to the published version of the manuscript.

Funding: This research received no external funding.

Institutional Review Board Statement: Not applicable.

Informed Consent Statement: Informed consent was obtained from all subjects involved in the study.

Data Availability Statement: Data presented in this study are available on request from the corresponding author.

Acknowledgments: The authors are grateful to Universiti Sains Malaysia for providing facilities in this study.

Conflicts of Interest: The authors declare no conflict of interest. 


\section{Appendix A}

Table A1. List of items in the questionnaire.

\begin{tabular}{l} 
Personal Norms (PN) \\
PN1: I would feel guilty if I bought non-eco-friendly clothing \\
PN2: I would be a better person if I purchased eco-friendly clothing \\
PN3: When I buy new clothing, I feel morally obligated to prioritise selecting eco-friendly clothing over the alternatives \\
PN4: I am willing to put extra effort into searching for eco-friendly clothing on a regular basis. \\
Social Norms (SN) \\
SN1: Family members whose opinion I value would approve of my engagement in pro-environmental behaviour \\
SN2: Family members whose opinion I value would approve of my engagement in purchasing eco-friendly clothing \\
SN3: Close friends who are important to me would support my engagement in purchasing eco-friendly clothing \\
SN4: The public would endorse my engagement in purchasing eco-friendly clothing \\
\hline Environmental Awareness (EA) \\
EN1: I am extremely worried about the state of the environment \\
EN2: I become upset when I think about the harm being done to plant and animal life by pollution. \\
EN3: I think that a person should urge their friends not to use products that pollute or harm the environment. \\
EN4: I try to buy products in environmentally safe packages \\
Sustainable Fashion Consumption (SFC)
\end{tabular}

SFC1: People should consider resource conservation when they buy clothes.

SFC2: I will not buy products that have excessive packaging.

SCF3: If I understand the potential damage to the environment that some products can cause, I do not purchase them

SCF4: I minimise buying fast fashion because they are not environmental-friendly products.

SCF5: I do not mind giving up certain fashion design elements for environmental protection purposes.

SCF6: If there is no difference in style between the two garments, I will choose the one with the eco-tags

\section{Facilitating Conditions (FC)}

FC1: I know how to recycle my unwanted clothing.

FC2: I know where I can dispose of my unwanted clothing.

FC3: I know a place to sell my packaging waste

FC4: There are enough facilities to dispose of unwanted clothing.

FC5: Recycling my unwanted clothing is convenient

Philanthropic Clothing Disposal Behaviour (PCDB)

\section{Give family and friends (PCDB.FF)}

PCDB1: Give away unwanted clothing to family/friends.

PCDB2: I give unwanted clothing to family members.

PCDB3: I give unwanted clothing to friends

PCDB4: I swap clothing with family members and friends

\section{Give Charity (PCDB.CH)}

PCDB5: It's important to give clothing to charity for needy people

PCDB6: I feel good when I give clothing to charity shops

PCDB7: I only give quality clothing to charity.

\section{Economically Clothing Disposal Behaviour (ECDB)}

ECDB1: I sell unwanted clothing to reduce the garbage disposal problem

ECDB2: I sell old clothing for environmental reasons

ECDB3: I resell clothing to recycle the garments that are in good condition

ECDB4: I sell much of clothing for economic reasons

\section{References}

1. Bernardes, J.; Marques, A.D.; Nogueira, M.; Ferreira, F. Consumers'clothing disposal behaviour: Where do we stand? In Proceedings of the 19th World Textile Conference-Autex 2019, Brussels, Belgium, 19-22 February 2019.

2. Wai Yee, L.; Hassan, S.H.; Ramayah, T. Sustainability and philanthropic awareness in clothing disposal behavior among young Malaysian consumers. SAGE Open 2016, 6, 2158244015625327. [CrossRef]

3. Byun, S.-E.; Sternquist, B. Fast fashion and in-store hoarding: The drivers, moderator, and consequences. Cloth. Text. Res. J. 2011, 29, 187-201. [CrossRef]

4. Zamani, B.; Sandin, G.; Peters, G.M. Life cycle assessment of clothing libraries: Can collaborative consumption reduce the environmental impact of fast fashion? J. Clean. Prod. 2017, 162, 1368-1375. [CrossRef]

5. Brewer, M.K. Slow fashion in a fast fashion world: Promoting sustainability and responsibility. Laws 2019, 8, 24. [CrossRef] 
6. Ro, C. Can Fashion Ever Be Sustainable? Smart Guide to Climate Change. 2020. Available online: https://www.bbc.com/future/ article/20200310-sustainable-fashion-how-to-buy-clothes-good-for-the-climate (accessed on 1 March 2021).

7. Ellen MacArthur Foundation. A New Textiles Economy: Redesigning Fashion's Future. 2017. Available online: https:// ellenmacarthurfoundation.org/a-new-textiles-economy (accessed on 20 July 2021).

8. Laitala, K. Consumers' clothing disposal behaviour-A synthesis of research results. Int. J. Consum. Stud. 2014, 38, 444-457. [CrossRef]

9. Goworek, H.; Oxborrow, L.; Claxton, S.; McLaren, A.; Cooper, T.; Hill, H. Managing sustainability in the fashion business: Challenges in product development for clothing longevity in the UK. J. Bus. Res. 2020, 117, 629-641. [CrossRef]

10. Wei, X.; Jung, S. Understanding Chinese consumers' intention to purchase sustainable fashion products: The moderating role of face-saving orientation. Sustainability 2017, 9, 1570. [CrossRef]

11. Joung, H.-M. Fast-fashion consumers' post-purchase behaviours. Int. J. Retail Distrib. Manag. 2014, 42, 688-697. [CrossRef]

12. Bray, J.; Johns, N.; Kilburn, D. An exploratory study into the factors impeding ethical consumption. J. Bus. Ethics 2011, 98, 597-608. [CrossRef]

13. Borusiak, B.; Szymkowiak, A.; Horska, E.; Raszka, N.; Żelichowska, E. Towards building sustainable consumption: A study of second-hand buying intentions. Sustainability 2020, 12, 875. [CrossRef]

14. Park, H.J.; Lin, L.M. Exploring attitude-behavior gap in sustainable consumption: Comparison of recycled and upcycled fashion products. J. Bus. Res. 2020, 117, 623-628. [CrossRef]

15. Zhang, B.; Zhang, Y.; Zhou, P. Consumer attitude towards sustainability of fast fashion products in the UK. Sustainability 2021, 13, 1646. [CrossRef]

16. Joanes, T. Personal norms in a globalised world: Norm-activation processes and reduced clothing consumption. J. Clean. Prod. 2019, 212, 941-949. [CrossRef]

17. Lundblad, L.; Davies, I.A. The values and motivations behind sustainable fashion consumption. J. Consum. Behav. 2016, 15, 149-162. [CrossRef]

18. Egmond, C.; Bruel, R. Nothing is as Practical as a Good Theory: Analysis of Theories and a Tool for Developing Interventions to Influence Energy-Related Behaviour. 2007. Available online: http://www.energy-behave.net/pdf/paper_final_draft_CE1309.pdf (accessed on 20 April 2021).

19. Triandis, H.C. Theoretical framework for evaluation of cross-cultural training effectiveness. Int. J. Intercult. Relat. 1977, 1, 19-45. [CrossRef]

20. Ajzen, I.; Fishbein, M. Understanding Attitudes and Predicting Social Behaviour; Prentice-Hall: Englewood Cliffs, NJ, USA, 1980.

21. Fishbein, M.; Ajzen, I. Belief, Attitude, Intention, and Behavior: An Introduction to Theory and Research; Addison-Wesley: Reading, MA, USA, 1975.

22. White, K.; Habib, R.; Hardisty, D.J. How to SHIFT consumer behaviors to be more sustainable: A literature review and guiding framework. J. Mark. 2019, 83, 22-49. [CrossRef]

23. Amin, H.; Abdul-Rahman, A.-R.; Abdul-Razak, D. Malaysian consumers' willingness to choose Islamic mortgage products. Int. J. Bank Mark. 2016, 34, 868-884. [CrossRef]

24. Sung, K.; Cooper, T.; Kettley, S. Factors influencing upcycling for UK makers. Sustainability 2019, 11, 870. [CrossRef]

25. Bamberg, S.; Schmidt, P. Incentives, morality, or habit? Predicting students' car use for university routes with the models of Ajzen, Schwartz, and Triandis. Environ. Behav. 2003, 35, 264-285. [CrossRef]

26. Issock, P.B.; Roberts-Lombard, M.; Mpinganjira, M. Understanding household waste separation in South Africa. Manag. Environ. Qual. Int. J. 2020, 31, 530-547. [CrossRef]

27. Shim, S. Environmentalism and consumers' clothing disposal patterns: An exploratory study. Cloth. Text. Res. J. 1995, 13, 38-48. [CrossRef]

28. Bianchi, C.; Birtwistle, G. Consumer clothing disposal behaviour: A comparative study. Int. J. Consum. Stud. 2012, 36, 335-341. [CrossRef]

29. Sulek, M. On the modern meaning of philanthropy. Nonprofit Volunt. Sect. Q. 2010, 39, 193-212. [CrossRef]

30. Chang, G.H.; Park, J.O. The effects of the socially responsible clothing consumption attitude on the clothing disposition behavior. J. Korean Soc. Cloth. Text. 1997, 21, 795-805.

31. Park, H.-H.; Choo, T.-G.; Ku, Y.-S. The influence of shopping orientation on difficulty discarding and disposal behavior of fashion products. Fash. Text. Res. J. 2016, 18, 833-843. [CrossRef]

32. Domina, T.; Koch, K. Consumer reuse and recycling of post-consumer textile waste. J. Fash. Mark. Manag. Int. J. 1999, 3, 346-359. [CrossRef]

33. Koch, K.; Domina, T. Consumer textile recycling as a means of solid waste reduction. Fam. Consum. Sci. Res. J. 1999, 28, 3-17. [CrossRef]

34. Joung, H.-M.; Park-Poaps, H. Factors motivating and influencing clothing disposal behaviours. Int. J. Consum. Stud. 2013, 37, 105-111. [CrossRef]

35. Harland, P.; Staats, H.; Wilke, H.A. Explaining proenvironmental intention and behavior by personal norms and the Theory of Planned Behavior. J. Appl. Soc. Psychol. 1999, 29, 2505-2528. [CrossRef]

36. Schwartz, S.H. Normative explanations of helping behavior: A critique, proposal, and empirical test. J. Exp. Soc. Psychol. 1973, 9 , 349-364. [CrossRef] 
37. Hwang, C.G.; Lee, Y.-A.; Diddi, S. Generation Y's moral obligation and purchase intentions for organic, fair-trade, and recycled apparel products. Int. J. Fash. Des. Technol. Educ. 2015, 8, 97-107. [CrossRef]

38. Diddi, S.; Yan, R.N.; Bloodhart, B.; Bajtelsmit, V.; McShane, K. Exploring young adult consumers' sustainable clothing consumption intention-behavior gap: A Behavioral Reasoning Theory perspective. Sustain. Prod. Consum. 2019, 18, 200-209. [CrossRef]

39. Pristl, A.C.; Kilian, S.; Mann, A. When does a social norm catch the worm? Disentangling social normative influences on sustainable consumption behaviour. J. Consum. Behav. 2021, 20, 635-654. [CrossRef]

40. Demarque, C.; Charalambides, L.; Hilton, D.J.; Waroquier, L. Nudging sustainable consumption: The use of descriptive norms to promote a minority behavior in a realistic online shopping environment. J. Environ. Psychol. 2015, 43, 166-174. [CrossRef]

41. Doran, R.; Larsen, S. The relative importance of social and personal norms in explaining intentions to choose eco-friendly travel options. Int. J. Tour. Res. 2016, 18, 159-166. [CrossRef]

42. Hanss, D.; Böhm, G.; Doran, R.; Homburg, A. Sustainable consumption of groceries: The importance of believing that one can contribute to sustainable development. Sustain. Dev. 2016, 24, 357-370. [CrossRef]

43. Bianchi, C.; Gonzalez, M. Exploring sustainable fashion consumption among eco-conscious women in Chile. Int. Rev. Retail Distrib. Consum. Res. 2021, 31, 375-392. [CrossRef]

44. Ho, T.T.H.; Vu, T.N.P.; Vu, H.M. Determinants influencing consumers purchasing intention for sustainable fashion: Evidence from Ho Chi Minh City. J. Asian Financ. Econ. Bus. 2020, 7, 977-986. [CrossRef]

45. Kong, H.M.; Ko, E.; Chae, H.; Mattila, P. Understanding fashion consumers' attitude and behavioral intention toward sustainable fashion products: Focus on sustainable knowledge sources and knowledge types. J. Glob. Fash. Mark. 2016, 7, 103-119. [CrossRef]

46. Puspita, H.; Chae, H. An explorative study and comparison between companies' and customers' perspectives in the sustainable fashion industry. J. Glob. Fash. Mark. 2021, 12, 133-145. [CrossRef]

47. Jackson, T. Negotiating sustainable consumption: A review of the consumption debate and its policy implications. Energy Environ. 2004, 15, 1027-1051. [CrossRef]

48. Cho, E.; Gupta, S.; Kim, Y.K. Style consumption: Its drivers and role in sustainable apparel consumption. Int. J. Consum. Stud. 2015, 39, 661-669. [CrossRef]

49. Chen, B.; Lee, J. Household waste separation intention and the importance of public policy. Int. Trade Politics Dev. 2020, 4, 61-79. [CrossRef]

50. Feiam, A. What Does the Average Fast Fashion Shopper Look Like? 2019. Available online: https://powerretail.com.au/infocus/what-does-the-average-fast-fashion-shopper-look-like/ (accessed on 25 December 2021).

51. Santrock, J.W. Life-Span Development, 18th ed.; McGraw-Hill Education: New York, NY, USA, 2020.

52. Hair, J.F., Jr.; Sarstedt, M.; Hopkins, L.; Kuppelwieser, V.G. Partial least squares structural equation modeling (PLS-SEM): An emerging tool in business research. Eur. Bus. Rev. 2014, 26, 106-121. [CrossRef]

53. Kim, S.H.; Seock, Y.-K. The roles of values and social norm on personal norms and pro-environmentally friendly apparel product purchasing behavior: The mediating role of personal norms. J. Retail. Consum. Serv. 2019, 51, 83-90. [CrossRef]

54. Butler, S.M.; Francis, S. The effects of environmental attitudes on apparel purchasing behavior. Cloth. Text. Res. J. 1997, 15, 76-85. [CrossRef]

55. Moon, K.K.-L.; Lai CS, Y.; Lam EY, N.; Chang, J.M. Popularisation of sustainable fashion: Barriers and solutions. J. Text. Inst. 2015, 106, 939-952. [CrossRef]

56. Botetzagias, I.; Dima, A.-F.; Malesios, C. Extending the theory of planned behavior in the context of recycling: The role of moral norms and of demographic predictors. Resour. Conserv. Recycl. 2015, 95, 58-67. [CrossRef]

57. Hair, J.F., Jr.; Sarstedt, M.; Ringle, C.M.; Gudergan, S.P. Advanced Issues in Partial Least Squares Structural Equation Modeling; Sage Publications: Thousand Oaks, CA, USA, 2017.

58. Fornell, C.; Larcker, D.F. Structural equation models with unobservable variables and measurement error: Algebra and statistics. J. Mark. 1981, 18, 382-388. [CrossRef]

59. Henseler, J.; Hubona, G.; Ray, P.A. Using PLS path modeling in new technology research: Updated guidelines. Ind. Manag. Data Syst. 2016, 116, 2-20. [CrossRef]

60. Cohen, J. Statistical Power Analysis for the Behavioral Sciences, Revised ed.; Academic Press: New York, NY, USA, 2013.

61. Fornell, C.; Cha, J. Partial least squares. In Advanced Methods of Marketing Research; Bagozzi, R.P., Ed.; Blackwell: Cambridge, UK, 1994; pp. 52-78.

62. Song, Y.; Qin, Z.; Yuan, Q. The impact of eco-label on the young Chinese generation: The mediation role of environmental awareness and product attributes in green purchase. Sustainability 2019, 11, 973. [CrossRef]

63. Bly, S.; Gwozdz, W.; Reisch, L.A. Exit from the high street: An exploratory study of sustainable fashion consumption pioneers. Int. J. Consum. Stud. 2015, 39, 125-135. [CrossRef]

64. Voisin, D.; Gosling, P.; Amoura, C.; Miraucourt, D.; Weber, T.; Dappe, Q. If they are all green, I take responsibility for my eco-unfriendly behaviors: Effects of injunctive norm on sense of responsibility following cognitive dissonance. Int. Rev. Soc. Psychol. 2020, 33, 5. [CrossRef]

65. Strähle, J.; Klatt, L.M. The second hand market for fashion products. In Green Fashion Retail; Strähle, J., Ed.; Springer: Singapore, 2017; pp. 119-134. 
66. Agency. Buying and selling second-hand fashion items is now a very lucrative business. In The Star; The Star: Petaling Jaya, Malaysia, 2021.

67. Kazancoglu, I.; Kazancoglu, Y.; Kahraman, A.; Yarimoglu, E.; Soni, G. Investigating barriers to circular supply chain in the textile industry from Stakeholders' perspective. Int. J. Logist. Res. Appl. 2020. Available online: https:/ /www.tandfonline.com/doi/full/ 10.1080/13675567.2020.1846694?scroll=top\&needAccess=true (accessed on 1 December 2021). 